Article

\title{
Building Sustainable Smallholder Cooperatives in Emerging Market Economies: Findings from a Five-Year Project in Kenya
}

\author{
John E. Meador ${ }^{1}$, David J. O'Brien ${ }^{2, *}$, Michael L. Cook ${ }^{3}$, Greg Grothe ${ }^{4}$, LuAnn Werner ${ }^{4}$, \\ Daniel Diang'a ${ }^{5}$ and Rebecca M. Savoie ${ }^{2}$ \\ 1 Rural Policy Centre, Scotland's Rural College, Edinburgh EH9 3JG, UK; elliot.meador@sruc.ac.uk \\ 2 Department of Rural Sociology, University of Missouri, Columbia, MO 65211, USA; \\ rmshf6@mail.missouri.edu \\ 3 Department of Agricultural and Applied Economics, University of Missouri, Columbia, MO 65211, USA; \\ Cookml@missouri.edu \\ 4 Land O'Lakes International Development, Shoreview, MN 55126, USA; GDGrothe@landolakes.com (G.G.); \\ LMWerner@landolakes.com (L.W.) \\ 5 Land O'Lakes International Development, P.O. Box 45006 G.P.O. 00100, Nairobi, Kenya; \\ daniel.dianga@idd.landolakes.com \\ * Correspondence: obriendj@missouri.edu; Tel.: +1-573-356-3711
}

Academic Editor: Tan Yigitcanlar

Received: 16 April 2016; Accepted: 7 July 2016; Published: 11 July 2016

\begin{abstract}
A comparative study of two smallholder dairy cooperatives in Kenya examines the question: what factors are conducive to producing sustainable smallholder cooperatives that can gain entry into the vertical value chain in liberalized post-colonial economies? The relative weight of income advantage; selective individual incentives and, social capital on maintaining member patronage are assessed within variable environmental constraints and opportunities facing different cooperatives. The methodology includes case study observation of the cooperatives during a five-year period, as well as sample surveys of members and non-members that include indicators of dairy income; reasons why farmers elect to join or not join the cooperative; and assessments of the importance of different services provided by the cooperative. The findings show how the relative weight of specific incentives for cooperative membership can vary from one environment to another within the same nation. The most important finding is that maintaining sustainable smallholder cooperatives within an increasingly competitive environment depends on the ability of managers to create business strategies that are compatible with the cooperative's environmental constraints but, at the same time, incentivize members' patronage.
\end{abstract}

Keywords: smallholder dairy cooperatives; Kenya; social capital; development; emerging economies

\section{Introduction}

The liberalization of post-colonial economies in parts of the developing world presents unique opportunities and challenges to smallholder cooperatives. This involves not only movement away from a centralized/command economy toward market oriented exchanges but also other major institutional changes affecting cooperative law policies and practices. In many instances, these countries were left with boilerplate cooperative laws suitable for a colony, with a great deal of central control and authority, and for many citizens this resulted in a distorted perception of what was the purpose of a cooperative. The transition to a market economy has resulted in increases in the standard of living of some portion of the population and this, in turn, has increased demand for what these farmers' produce. At the same time, however, liberalization has meant that smallholder cooperatives now have to compete with 
multi-national agricultural firms, as well as medium to large local farms, while national governments are much more likely to make the cooperatives responsible for their debts. Consequently, in order to survive smallholder cooperatives must develop effective business plans and practice if they are to remain sustainable in the new environment [1-3].

In developing these business plans, models, and objectives, cooperative leaders must incorporate the unique feature that sets them apart from private or investor-owned firms; namely, that they are patron-driven rather than investor-driven [4]. In the case of smallholder dairy cooperatives, this means members selling their milk to the cooperative and / or purchasing services that the cooperative offers, or other terms as defined in the bylaws. In the competitive environment in the newly-liberalized economies this can be challenging since smallholder farmers now have other options with respect to where they sell their milk and/or where they purchase inputs and services for their farms.

The critical question, then, is what motivates smallholder farmers to sell their milk and/or purchase other services from the cooperative? In the development literature a great deal of attention has been given to micro-credit and micro-enterprise associations that are embedded in village-level institutions that support cooperation and mutual trust [5]. From an organizational design point of view, these small-scale organizations contain the collective action advantages of small groups, where interpersonal relations provide self-monitoring devices to keep them pointed toward goals that will benefit the whole group [6] (pp. 22-42). This organizational form, then, contains high levels of bonding social capital than insures trust and social support networks [7].

These local entities have served an important role in helping their customers build a credit history. By themselves, however, the small village-level micro-credit or micro-enterprise associations are not capable of competing as commercial entities with other firms in the newly-liberalized economies and, thus, their impact on the development of sustainable sources of income for smallholders is limited [8]. To become competitive in the emerging marketplace, smallholder cooperatives must develop more complex bridging [7] social networks that can support their participation in more complex value chains [9] where they extract a dual set of rents, at the household and at the cooperative levels, by gaining access to financial benefits from processing, marketing, and establishing profitable brand names [10].

Our thesis in this paper is that in order to develop an analytical approach to the changing environment in which smallholder cooperatives must operate, it is necessary to examine general social science approaches to collective action. This includes both an understanding of the different types of incentives that might induce smallholder farmer engagement but also the extent to which changing features of regional and local environments in the life cycle [11] of each cooperative will influence the effectiveness of these inducements. We will focus on the relative impact of (1) income advantage through countervailing power; (2) selective individual benefits; and (3) social capital as sources of member patronage in smallholder dairy cooperatives within the newly-liberalized economy in Kenya.

\subsection{Approaches to Member Engagement in Collective Action}

The social science literature on collective action in economic affairs, of which cooperatives are a subset, contains a number of different theoretical approaches, all of which address the question: why would a rational self-interested individual join a collective effort rather than pursue an individual strategy in the marketplace? Let us look at each of these in turn.

\subsubsection{Income Generation through Countervailing Power}

To gain some perspective on how sustainable agricultural cooperatives are developed, it is helpful to look at the historical evolution of this organizational form in Western countries. American agricultural cooperatives, for example, emerged as an outgrowth of social movements in the 19th and early 20th century that focused on improving the ability of farmer producers to achieve countervailing power to deal with the concentration of ownership of railroads and grain elevators. These cooperatives evolved to the point where not only did they achieve countervailing power but eventually were able to increase farmer members' income through vertical integration [4]. 
The critical question for our purposes is to what extent does income provide a sufficient incentive for contemporary smallholder farmers to maintain membership in a dairy cooperative? There is support for the notion that increasing income can be a powerful incentive for small farmers to act collectively. The success of the cooperative movement in the New Zealand dairy industry, for example, illustrates how collective action can lead to vertical integration that will substantially increase small producer income [12].

Other case studies indicate that although increasing household income is important, a more compelling motivation for many smallholder farmers is to preserve their communities, while at the same time adapting to exigencies of a liberalizing economy. This is seen, for example, in the case of the Mennonites in Paraguay who have employed collective entrepreneurship to preserve their religious community [13]. Even more compelling is the case of the Nunavik in Arctic Quebec who were able to preserve the core of their indigenous culture while transitioning an economy based on the social organization of small family bands to a complex, collective, entrepreneurial-oriented social organization. This organizational adjustment brought increased income to households but, more importantly, provided a sustainable way to fit into a global economy [14].

New institutional economists have observed that a critical element in becoming competitive in the marketplace is to reduce transaction costs [15]. This is especially important for smallholders who lack assets and access to information and thus provides a rationale for collective action through cooperatives [16-18]. Research studies from a variety of national locations have confirmed that collective action through cooperatives can provide bargaining power for smallholders [19]. Nonetheless, there also is compelling evidence that countervailing power, in itself, is not a sufficient cause for the success of smallholder cooperatives $[17,20]$.

\subsubsection{Selective Benefits}

Mancur Olson's classic, The Logic of Collective Action, proposes that when a group is large, which he calls a latent group, one strategy for inducing individuals to become members of a collective organization that pursues a common good or objective is to provide a selective individual benefit that can be received only when an individual contributes to the cost of the collective good [6] (pp. 132-166). This strategy is found in a host of collective organizations, professional associations, and farm lobby organizations. In the case of smallholder cooperatives this strategy might include, for example, lower cost access to farm inputs, such as feed or fertilizer, either at a reduced price and/or by providing credit for purchase or some type of technical assistance in farm management that could only be obtained by being a member in good standing of the cooperative. Moreover, cooperatives also provide technical information on ways to take advantage of new collective entrepreneurial opportunities [10]. The critical question here is, to what extent does the provision of selective benefits provide an incentive for smallholder members to patronize their cooperative?

Like farmers everywhere, smallholder farmers in emerging economies increasingly face the need to access knowledge about scientific innovations that will increase production and lower costs, as well as identify market niches where their products are competitive [21,22]. Research has found that these farmers are rational actors, who are aware of this need and do not have any aversion to new information that will make their farming operations more sustainable [23].

A recent study in Tunisia, for example, illustrates how collective organizations can provide new innovations for smallholders. In this case, "communities of practice" created practical opportunities for peer learning of ways to improve smallholders' farming practices [24].

\subsubsection{Social Capital}

Countervailing power and/or selective incentives may be a necessary, but are not a sufficient, condition to support sustained individual contributions to collective action organizations. A growing body of research has demonstrated that an additional requirement is building and maintaining trust and social network ties, which falls under the general rubric of social capital [7]. Thus, for example, in addition to their common economic interests, American farmers seeking to form cooperatives in 
the 19th and early 20th centuries had a large reservoir of social capital. This social capital of trust and reciprocal supportive social network relationships was built in small rural communities where farm families were members of local churches and their children attended local schools. In addition to generating support for the cooperative movement in the first place, it also was a key player in the early 20th century progressive movement in American politics which, in addition to changing many institutional elements at all levels of government, also supported enabling federal and state legislation, such as exemptions to anti-trust laws, securities waivers, and single-issue provisions that have made cooperatives an institutional and organizational alternative to either an unfettered, unregulated market or a top-down command economy [25].

Most important is the fact that not only is social capital an exogenous factor that can support collective action, but it is something that can be built, or lost, by specific institutional and organizational arrangements, which have to be adjusted to meet new exigencies [26]. In a recent survey of cooperative performance, using financial indicators as dependent variables, the level of social capital, measured by processes for communication between members and the board, especially feedback loops so that members could provide input into board decisions, was found to be a more important predictor of member satisfaction and overall financial success than some other structural factors that have been found to be important in investor-owned firms. Communication channels, voting policies, timing, and the format of member meetings were found to be essential in the ability of boards to obtain member feedback, which, in turn, was critical to their performance [27].

The historical colonial experience of smallholder Kenyan farmers, which lies in the not too distant past, is by no means comparable to the independent free farmers in America, supported initially by the Homestead Act. Nonetheless, the informal institutional fabric in many local communities in Africa, which predates colonialism, does provide informal institutional support to generate social capital that can play a significant role in inducing individual smallholder farmers to become and maintain their membership in cooperatives. The challenge here is whether, in addition to bonding social capital, smallholder cooperatives can develop effective business models that can adapt to a more liberalized environment, but that also maintain the patronage of their members. This means the development of bridging, as well as bonding ties [7,9].

The examples of the Mennonite community in Paraguay [13] and the Nunavik in the Artic [14] provide good illustrations of how traditional social capital-i.e., trust and bonding social networks - can actually facilitate the development of bridging ties to the outside world, essentially because it provides a powerful motivation for adaption to the outside world if the group is to survive. Although the cultures and market challenges were, in many ways, quite different, each managed to build bridging ties that facilitated collective entrepreneurship while preserving the core values of their respective communities.

\subsection{Environmental Constraints on the Effectiveness of Member Engagement Strategies}

The relative effectiveness of each of the three sources of member engagement described above must be understood within the context of the exigencies and opportunities presented at different levels of analysis. This means that the crucial challenge facing cooperative leadership is to comprehend and then to develop effective strategies to deal with these contexts.

\subsubsection{Institutional Arrangements at the National-Level}

Changes in national-level institutional arrangements can provide both opportunities and constraints for smallholder cooperatives. On the one hand, institutional arrangements can provide certain advantages to cooperatives, such as access to credit through a cooperative bank, as well as certain tax advantages. On the other hand, in countries that are transitioning from a command to a more liberalized economy, institutional changes typically foster competition that can create serious challenges to cooperatives that were used to operating in a non-competitive environment. This can include, for example, no longer forgiving debts that a cooperative has accumulated through ineffective business practices. Most important, liberalizing the institutions governing the marketplace, as well as increased consumer demand, generates an incentive for larger and more powerful multi-national firms to become rivals of smallholder cooperatives. 


\subsubsection{Regional Markets}

At this level of analysis we are concerned with the actual market within which a cooperative must compete, especially the current, as well as future, number and market share of its rivals. Although all cooperatives are affected in significant ways by institutional arrangements at the national level, the actual markets they compete in can be different from one milkshed to another. This is challenging because the environment at this level is subject to major changes during the transition from the command to the market economy. Competition can differ from one region to another within the same country. The critical question, then, is how does the market in different regions, and cooperative leadership's recognition and responses to it, influence the effectiveness of different incentives to encourage member engagement?

\subsubsection{Cooperative and Member Level}

Cooperative leadership faces two interdependent challenges to develop a business strategy that: (1) takes account of the unique market-level constraints and opportunities, but also (2) engages members to be dedicated users/patrons that is essential for the cooperative to be sustainable. This requires efforts similar to that of any investor-owned firm to expand market share, diversify products, etc., but also presents internal management challenges that are unique to the cooperative structure, especially understanding the types of incentives that are attractive to members to ensure that they are fully engaged and active.

\section{Materials and Methods: Research Design}

The findings described below are based on qualitative and quantitative data from two case studies of smallholder dairy cooperatives in Kenya during a five-year period, from 2011 to 2015 [3]. The project provided both baseline and endline data based on cooperative financial performance, interviews with cooperative leaders, and the impact of the donor agency's technical assistance on changes in their business plans and practices. In addition, the project included baseline and endline surveys of cooperative members and non-members in 2011 and 2015 [28]. These surveys provide quantitative indicators of what accounted for members' patronage in the different time periods, their assessment of the impact of changes in cooperative leadership, and the specific reasons why they evaluated their respective cooperatives as more or less beneficial to them.

The two cooperatives described in the paper are part of a Cooperative Development Project (CDP), funded by USAID and led by Land O'Lakes International Development [3]. At the outset of the project, these cooperatives were developing plans to take advantage of the demand for milk and value-added dairy products in the growing Kenyan economy. At the same time, macro-level institutional changes put in place by the Kenyan government in the 1990s provided an opportunity for large dairy processing entities, such as Brookside, which is a co-investor with Danone, and New KCC, who already had a large share of the market (roughly 71 percent) to expand, and for new competitors, like Daima (Sameer), to enter, thus increasing the pressure on smallholder cooperatives to develop new strategies to remain sustainable in this rapidly-changing environment.

An inter-disciplinary team of experts in business finance, processing plant operations, cooperative board management, agricultural economics, and rural sociology gathered empirical data on past and potential future cooperative performance as a business entity but, equally important, provided indicators to understand the current state of member patronage in their cooperative and how that might affect strategy going forward. The researchers also obtained quantitative survey data on member and non-member farms, including income, reasons for joining or not joining the cooperative, and statistical associations between satisfaction with the cooperative and specific benefits that they received from their membership [28]. The data from the baseline was shared with the cooperatives' management and member elected boards. This, in turn, provided an empirical basis for various kinds of technical support and training that was provided by Land O'Lakes personnel in Kenya and in two workshops, one in Nairobi and one in India. 
In contrast to many technical assistance programs, the CDP operated under the core premise that a cooperative in a competitive business environment could only be sustainable if members took ownership of decisions about strategy. Thus, although Land O'Lakes provided empirical data support and specific training opportunities for cooperative board members, members themselves were ultimately responsible for making decisions about leadership and business strategy.

At the baseline both of the cooperatives were operating a processing plant that pasteurized and packaged milk that was obtained from smallholder farmers, but they were also looking at ways to gain further entry into the value chain by improving their plant's capacity to produce value added products like yoghurt and long shelf milk. One cooperative, which will be referred to as the Large Metro Area Cooperative, is located in the milk shed of the large metropolitan area of Nairobi, Kenya's capital. At the beginning of the project it was comprised of 9900 farmer members, with an average number of 2.2 milking cows. The other cooperative, which will be referred to as the Rural Area Cooperative, is located in a more rural area, a considerable distance from Nairobi. At the beginning of the project it was a federation of 17 primary cooperatives, which collected raw milk from 20,000 small producers with an average number of 1.9 milking cows. The challenges faced by the two cooperatives are vividly illustrated by the average utilization of their processing plants in 2011 . The Rural Area Cooperative's plant had an average plant utilization rate of only 20 percent, while the processing plant of the Large Metro Area Cooperative was operating at 43 percent capacity. The financial challenges facing the two cooperatives were exacerbated in part by investments in new equipment, but also by the fact that the Kenyan government was becoming more unwilling to continue the traditional practice of restructuring or outright forgiveness for cooperative debt.

\section{Results}

The results described below report on both case study observational and sample survey findings on cooperative members and non-members at the baseline, at the beginning of the study in 2011 and at the endline, the conclusion of the project in 2015, as well as a brief description of the project's technical assistance programs in the intervening years.

\subsection{Sources of Member Patronage at the Time of the Baseline}

The regression analysis shown in Table 1 indicates that, in 2011, there was little income advantage in being a member of a cooperative. There is a slight, less than one percent, gain in income for cooperative members (see Equation (1)). This effect disappears when smallholder household farm characteristics are introduced-i.e., how many cows milked, normal production per cow, and percent milk consumed (see Equation (4)). In Equation (5), there is a slight, less than a one percent increase in $R^{2}$, advantage for members of the Large Metro Area Cooperative.

Table 1. Baseline regression of dairy income (US\$ per month) on cooperative membership, household demographics, non-dairy income, current milk production and cooperative that a member belongs to (unstandardized coefficients on top; standard errors in parentheses).

\begin{tabular}{|c|c|c|c|c|c|}
\hline Independent Variables & Equation (1) & Equation (2) & Equation (3) & Equation (4) & Equation (5) \\
\hline Constant & $\begin{array}{l}63.729 \\
(7.298)\end{array}$ & $\begin{array}{c}27.621 \\
(29.777)\end{array}$ & $\begin{array}{c}43.470 \\
(29.477)\end{array}$ & $\begin{array}{l}-120.961 \\
(27.273)\end{array}$ & $\begin{array}{l}-81.260 \\
(29.562)\end{array}$ \\
\hline Age of Household Head & & $\begin{array}{l}0.000 \\
(0.373)\end{array}$ & $\begin{array}{l}-0.242 \\
(0.370)\end{array}$ & $\begin{array}{l}-0.381 \\
(0.319)\end{array}$ & $\begin{array}{l}-0.471 \\
(0.318)\end{array}$ \\
\hline $\begin{array}{l}\text { Female Head of Household } \\
\quad(1=\text { female head })\end{array}$ & & $\begin{array}{l}-24.802 * \\
(12.864)\end{array}$ & $\begin{array}{l}-25.157^{*} \\
(12.681)\end{array}$ & $\begin{array}{l}-14.085 \\
(10.865)\end{array}$ & $\begin{array}{l}-11.115 \\
(10.851)\end{array}$ \\
\hline Number of Persons in Household & & $\begin{array}{c}4.035 \\
(2.924)\end{array}$ & $\begin{array}{l}4.750 \\
(2.885)\end{array}$ & $\begin{array}{l}1.975 \\
(2.499)\end{array}$ & $\begin{array}{l}1.464 \\
(2.492)\end{array}$ \\
\hline
\end{tabular}


Table 1. Cont.

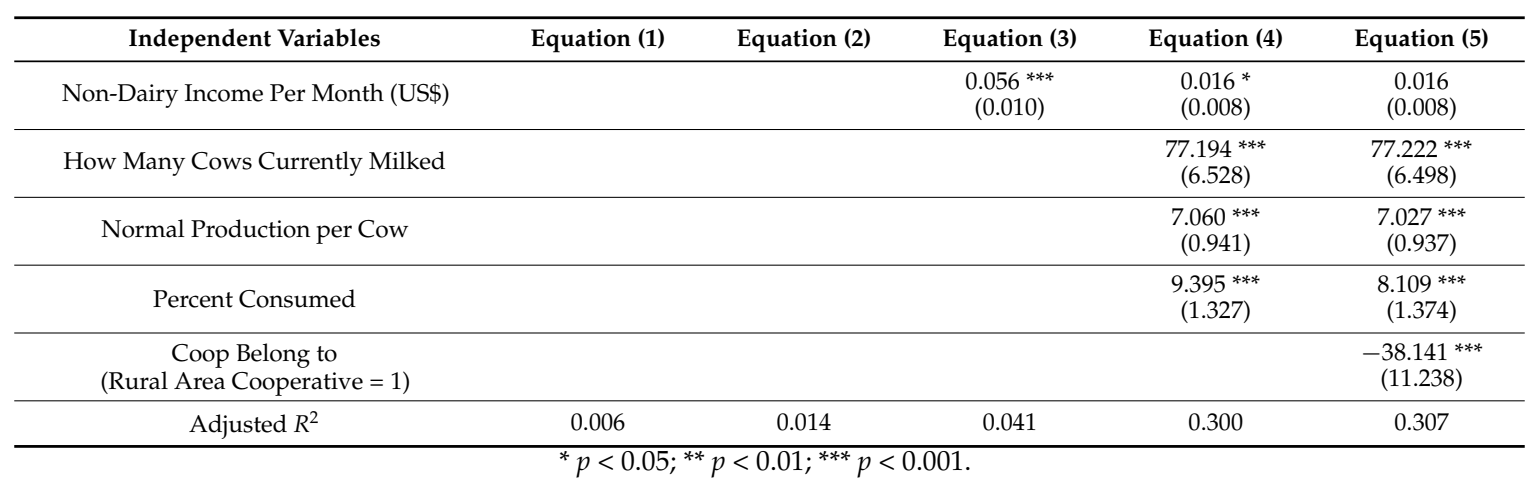

Table 2 shows that the majority of non-members (60 percent in each of the two milksheds) were motivated primarily by the price they received for their milk. They preferred to sell their milk to other buyers than the cooperative-schools, hospitals, hotels, and local door-to-door brokers known as "hawkers".

Table 2. Non-members' reasons for not joining the cooperative (in percent).

\begin{tabular}{ccc}
\hline Reasons for Not Joining & $\begin{array}{c}\text { Large Metro Area Cooperative } \\
(\boldsymbol{n}=\mathbf{1 3 4 )}\end{array}$ & $\begin{array}{c}\text { Rural Area Cooperative } \\
(\boldsymbol{n}=\mathbf{6 4 9 )}\end{array}$ \\
\hline Other buyers offer higher price & 63.0 & 61.9 \\
Poor cooperative services & 41.1 & 34.3 \\
Does not produce enough milk & 17.9 & 25.4 \\
Membership fees too expensive & 9.2 & 47.8 \\
Long distance to collection point & 10.6 & 16.2 \\
Conflict with cooperative & 10.3 & 18.7 \\
leadership & & \\
\hline
\end{tabular}

Why do some smallholders become members and sell their milk to the cooperative? The answers are shown in Table 3. The top reasons given for membership in both of the cooperatives falls under the rubric of either "selective benefits" or "social capital". Inputs on credit, training, and general credit are selective benefits that are available only to members who deliver milk to their respective cooperative. Timely payment for milk, convenient payment for milk, and stable prices over time fall under the rubric of efficient business practice, but over time, they also build up trust among the members. This dependable relationship, in turn, provides the cooperative with social capital with which to incentivize member patronage.

Table 3. Benefits of membership reported by members at the baseline (in percent).

\begin{tabular}{ccc}
\hline Reasons for Joining & $\begin{array}{c}\text { Large Metro Area Cooperative } \\
(\boldsymbol{n}=\mathbf{1 7 4})\end{array}$ & $\begin{array}{c}\text { Rural Area Cooperative } \\
(\boldsymbol{n}=\mathbf{7 0 5})\end{array}$ \\
\hline Purchase inputs on credit & 53.5 & 65.7 \\
Timely payment for milk & 41.4 & 31.9 \\
Convenient payment for milk & 41.4 & 32.9 \\
Training & 31.0 & 33.5 \\
General credit & 27.0 & 41.8 \\
Stable prices over time & 14.0 & 20.9 \\
Exchange visits & 4.6 & 9.5 \\
High milk price & 4.0 & 4.5 \\
\hline
\end{tabular}




\subsection{Land O'Lakes Technical Assistance Programs and Strategies for Member Engagement}

Our discussion so far highlights the fact that both cooperatives faced serious problems, including substantial debt and low plant utilization capacity, and yet significant numbers of smallholders in each milk shed believed that there were benefits to be realized by remaining members of their respective cooperatives. The Land O'Lakes technical support team and the cooperative leadership's challenge was to identify, through initial analytics, specific areas where the project could provide technical assistance to fill any critical gaps to help the cooperative become resilient in the face of change.

In addition to providing access to locally-based trained accountants and business planners and guidance on improved supply chain management, the team also provided workshop leadership learning experiences for management and cooperative board members, one in Nairobi and one in India; the latter setting providing an opportunity for the Kenyans to interact with smallholders who are members of some of the most successful smallholder dairy cooperatives. The workshops included representatives from cooperatives in many countries and participants were able to build up their network of cooperative managers and board members.

The specific direction that leadership in each of the cooperatives took mid-way through the five-year project was framed to respond to the different exigencies presented by their respective milkshed environments. The Large Metro Area Cooperative in the Nairobi area milk shed, for example, was faced with a greater degree of rivalry for raw milk than was the Rural Area Cooperative. Moreover, the demand for other food products in the Nairobi area was increasing and, thus, smallholder farmers now had the additional substitution option of investing in poultry or horticultural production. Moreover, a very large debt, that it was unable to re-structure, resulted in the Large Metro Area Cooperative's decision to stop processing milk at its plant, first leasing the processing facility to a competitor, but eventually using it simply as a storage facility.

The survival crisis facing the Large Metro Area Cooperative was ameliorated, at least for the time being, when the cooperative board hired new management, led by a young MBA with business management and planning skills. The new management began to search for other services that would provide selective incentives to attract members, but also generate income from non-members, that would provide a new source of income for the cooperative. This involved an organizational re-structuring toward backward integration, in which the cooperative invested more heavily in a dairy feed mill. In addition, the cooperative developed other selective incentives for members including an expanded credit program.

The Rural Area Cooperative, located some distance from Nairobi, faced a different milkshed environment, with less competition from rivals for smallholder farmers' milk. However, the new management of this cooperative also developed a more efficient business operation. This included creating a more efficient accounting system that resulted in more timely payments to members, establishing a cooperative-wide milk price that all primaries would have to pay their members, consolidating a more efficient route for milk collection, and clarifying the relationships and communication networks to the member-elected cooperative board and the management team they hired.

Most important, the more transparent and more efficient organizational structure introduced selective benefits to members who increasingly saw that, as several farmers put it, "we are in the dairy business for the long haul." Two of the most important of these were the newly-created extension service that provided training to members on ways to improve their dairy farm operations and bonuses for members who exceeded specific levels of milk production with a bonus payment in January.

These shifts in strategy by the Rural Area Cooperative's management produced a marked increase in member patronage, resulting in an increase in plant utilization capacity from 20 percent in 2011 to 70 percent in 2015 , as well as an increase in raw milk capacity. The cooperative is planning to purchase new equipment and building space to increase its capacity even further.

Providing selective benefits, like bonuses and extension training, has increased members' trust and incentives to remain in the cooperative; specifically, by reinforcing the belief that the cooperative can be depended upon by the members to treat them fairly, by delivering services and other forms of support as they seek to become more productive and profitable dairy farmers. The Rural Area Cooperative's members now sell 85 percent of the milk they produce to the cooperative, compared to 70 percent for members of the Large Metro Area Cooperative. 


\subsection{Comparing What Members' Perceived as Cooperative Benefits in the Endline Survey}

The "hard data" obtained at the endline assessment of the five-year project showed some substantial improvement in the financial condition of the Rural Area Cooperative, such as the increase in plant capacity utilization. The Large Metro Area Cooperative had been reduced to being exclusively a milk collection company, but, as noted earlier, they also increased their members' services.

On a measure of satisfaction with their cooperative, at the end of the five-year project, the Rural Area Cooperative's members had a much higher level of satisfaction than did the Large Metro Area Cooperative's members. When asked on a scale of one to ten-the Net Promoter Score [29]—question, "would you recommend your cooperative to relatives or friends", a majority of the Rural Area Cooperative's members (63.5 percent) gave their cooperative a score of 9 or 10, indicating that they were "promoters" of the organization. However, less than a majority (42.5 percent) of the members of the Large Metro Area Cooperative gave their organization a "promoter" score $(F(1)=15.751, p<0.001)$.

\subsection{How Important Is Dairy Income in Maintaining Member Loyalty?}

There are several ways of looking at changes in income for cooperative members in the two milksheds. If we look at gross farm level dairy income, the members of the Rural Area Cooperative have made substantial gains, from 53.25 US\$ per month in 2011 to 66.67 US\$ per month in 2015, for a statistically significant gain of 25.2 percent $(p<0.01)$. The gains in net farm level dairy income (self-reported income minus costs) are even stronger; 18.89 US \$ per month to 30.56 US $\$$ per month, for a gain of 61.8 percent $(<0.01)$. However, while the gross farm level dairy income for cooperative members in the milkshed is higher in 2015 than that of non-members-66.67 US\$ per month compared to 61.11 US\$ per month — their net farm level dairy income is actually lower; 30.56 US\$ per month compared to 34.24 US\$ per month [28] (pp. 34-35, Tables 9 and 10).

The gross farm level dairy income gains for members of the Large Metro Area Cooperative are less than those for members of the Rural Area Cooperative-106.49 US\$ per month to 108.07 US\$ per month from 2011 to 2015, which is a statistically non-significant change of 1.5 percent. The net farm level income for members of The Large Metro Area Cooperative actually declined from 31.69 US\$ per month in 2011 to 30.92 US\$ per month in 2015, for a drop of 2.4 percent. Moreover, while the gross farm level income from dairy for members of the Large Metro Area Cooperative is higher than that of non-members in their milkshed, 108.07 US\$ per month compared to 97.95 US\$ per month, net farm level income (self-reported income minus inputs) is less; 35.92 US\$ per month compared to 40.65 US\$ per month [28] (pp. 34-35, Tables 9 and 10).

Finally, it should be noted that when net dairy income is calculated by the value of milk production per cow, it appears that non-members actually have an advantage over cooperative members at the time of the endline in 2015; 21.67 US\$ for Rural Area Cooperative members and 29.50 US $\$$ for non-members in the same milkshed, and 15.88 US\$ for the Large Metro Area Cooperative members compared to 29.17 US\$ for non-members in the same milkshed [28] (p. 37, Table 12).

Several points are important to keep in mind in interpreting the relevance of the aforementioned to the central question addressed in this paper: what benefits do members see as important in maintaining their patronage in the cooperative? First, members, especially in the Rural Area Cooperative, have more cows being milked and spend more on inputs than do non-members [28] (p. 66, Table 39).

Second, at least in the case of the Rural Area Cooperative, the growth in gross and net income at the farm level from 2011 to 2015 could provide the member with a sense of relative improvement in his or her income. Moreover, as we saw earlier in Table 3, income advantage, per se, is not the primary reason why members maintain their patronage to the cooperative. 


\subsection{Selective Incentives, Social Capital, and Members' Satisfaction at the Endline}

Table 4 shows the percentage of members who cited specific services as a reason for belonging to their respective cooperative at the baseline in 2011 and at the endline in 2015. These services can be viewed as selective benefits that are obtained by becoming a member of the cooperative. The understanding by new management of the importance of these selective incentives as benefits of membership is reflected in the improvement in six out of the eight service areas in the Rural Area Cooperative and two out of the eight service areas in the Large Metro Area Cooperative.

Table 4. Benefits of membership reported by members at the baseline and endline (in percent).

\begin{tabular}{ccccc}
\hline \multirow{2}{*}{ Membership Benefits } & \multicolumn{2}{c}{ Large Metro Area Cooperative } & \multicolumn{2}{c}{ Rural Area Cooperative } \\
\cline { 2 - 5 } & $\begin{array}{c}\text { Baseline } \\
(\boldsymbol{n}=\mathbf{1 7 4})\end{array}$ & $\begin{array}{c}\text { Endline } \\
(\boldsymbol{n}=\mathbf{4 6 9 )}\end{array}$ & $\begin{array}{c}\text { Baseline } \\
(\boldsymbol{n}=\mathbf{7 0 5})\end{array}$ & $\begin{array}{c}\text { Endline } \\
(\boldsymbol{n}=\mathbf{5 8 4})\end{array}$ \\
\hline Purchase inputs on credit & 53.5 & 37.2 & 65.7 & $41.8^{* * *}$ \\
Timely Payment for milk & 41.4 & 43.3 & 31.9 & $58.1^{* * *}$ \\
Convenient Payment for milk & 41.4 & 47.0 & 32.9 & $60.0^{* * *}$ \\
Training & 31.0 & $23.3^{*}$ & 33.5 & $50.5^{* * *}$ \\
General credit & 27.0 & $40.6^{* *}$ & 41.8 & $39.3^{* *}$ \\
Stable prices over time & 13.2 & 6.3 & 7.2 & $33.9^{* * *}$ \\
Exchange visits & 4.6 & 5.4 & 9.5 & $23.2^{* * *}$ \\
High milk price & 4.0 & $9.3^{* *}$ & 4.5 & $20.6^{* * *}$ \\
\hline
\end{tabular}

Difference between baseline and endline percentages: ${ }^{*} p<0.10 ;{ }^{* *} p<0.05 ; * * * p<0.01$.

Overall, there was a greater increase in satisfaction with specific services as a benefit of membership in the Rural Area Cooperative than in the Large Metro Area Cooperative. Listing "milk price" as a benefit of membership increased in each cooperative, but by more than four times from the baseline to the endline in the Rural Area Cooperative ( $4.5 \%$ to $20.6 \%$ ), and only a little more than twice as much change from the baseline to the endline in the Large Metro Area Cooperative (4.0\% to 9.3\%). This is partly a reflection of an overall increase in gross and net farm level dairy income for Rural Area Cooperative members, including the new bonuses for members who exceed certain levels of milk sales (more than 70 percent of the Rural Area Cooperative's members reported receiving bonuses). Moreover, the Rural Area Cooperative's members reported substantial increases in "timely payment" (31.9\% to 58.1\%), "convenient payment" (32.9\% to 60.0\%), and "stable prices over time" (7.2\% to 33.9\%) as benefits for membership, but there were no statistically significant improvements in these service areas for the Large Metro Area Cooperative's members.

Two other critical services that have expanded for members of the Rural Area Cooperative, but not for members of the Large Metro Area Cooperative, were "access to training" (33.5\% to 50.5\%) and "exchange visits" ( $9.5 \%$ to $23.2 \%$ ). In fact, "access to training" as a benefit for membership actually decreased in the Large Metro Area Cooperative (31.0\% to 23.3\%). The one area where the Large Metro Area Cooperative has outpaced the Rural Area Cooperative in improving a member's service, however, is "access to general credit" $(27.0 \%$ to $40.6 \%)$. As noted earlier, the development of the loan program was part of the strategy developed by the new management to retain current members and to attract new ones.

Overall, the greater level of satisfaction of the Rural Area Cooperative's members, compared to their counterparts in the Large Metro Area Cooperative, which is reflected in the mean differences in total promoter scores, reflects a substantial growth in bridging social capital in the Rural Area Cooperative, in which the more efficient and in many ways more centralized administrative structure is supported by members because management also devotes considerable resources to building trust through more efficient collection routes and a hands-on extension program outreach to farmer members. This advantage is reflected in the logistic regression analysis shown in Table 5. 
Table 5. Logistic regression to predict membership in one or the other of two cooperatives by members' satisfaction with specific benefits ( $0=$ Large Metro Area Cooperative; $1=$ Rural Area Cooperative).

\begin{tabular}{|c|c|c|c|}
\hline Independent Variables & B & S.E. & Wald \\
\hline Milk testing requirements & $-0.862 * * *$ & 0.236 & 13.32 \\
\hline Accuracy of weighing and recording & $1.134^{* * *}$ & 0.23 & 24.431 \\
\hline Milk prices & $0.502 * *$ & 0.187 & 7.229 \\
\hline Timeliness of payments & -0.05 & 0.161 & 0.097 \\
\hline Treatment of members not meeting responsibilities & 0.465 * & 0.182 & 6.537 \\
\hline Relationships between cooperative members & -0.161 & 0.254 & 0.401 \\
\hline Relationships between members and management & $0.991^{* * *}$ & 0.205 & 23.382 \\
\hline Training and technical support & $0.809^{* * *}$ & 0.164 & 24.369 \\
\hline Participation of women in cooperative management & $0.968 * * *$ & 0.242 & 16.070 \\
\hline Leadership effort to promote participation of women in dairy & 0.313 & 0.23 & 1.859 \\
\hline Explanation of cooperative rules & -0.173 & 0.215 & 0.651 \\
\hline Cooperative leadership's communication to members & -0.159 & 0.219 & 0.526 \\
\hline Members' ability to communicate to cooperative leadership & 0.385 & 0.219 & 3.091 \\
\hline
\end{tabular}

The statistically significant coefficients shown in Table 5 indicate which specific characteristics would predict the odds that an individual member belongs to the Large Metro Area Cooperative or to the Rural Area Cooperative. The dummy variable is coded $0=$ Large Metro Area Cooperative and $1=$ Rural Area Cooperative; thus, positive coefficients increase the odds that an individual is a member of the Rural Area Cooperative, while a negative coefficient increases the odds that an individual is a member of the Large Metro Area Cooperative.

Six of the seven statistically significant variables predict that an individual will be a member of the Rural Area Cooperative. This includes, "accuracy of weighing and recording" (72.7 percent of Large Metro Area Cooperative versus 88.1 percent of the Rural Area Cooperative's members were satisfied) and "treatment of members not meeting their responsibilities" (66.0 percent of the Large Metro Area Cooperative's versus 86.3 percent of the Rural Area Cooperative's members were satisfied), the "relationship between cooperative membership and management" (57.2 percent of the Large Metro Area Cooperative's versus 91.2 percent of Rural Area Cooperative's members) reflects the view that members feel that management listens to them and responds to their concerns. The differences in the level of satisfaction with "participation of women in cooperative management" (66.2 percent of the Large Metro Area Cooperative's versus 90.0 percent of the Rural Area Cooperative's members) is important in terms of members' belief that the cooperative is treating everyone fairly and, thus, is a source of social capital that generates high levels of member engagement. In addition, this perception reflects a management culture in the Rural Area Cooperative that not only is more accepting of diversity but, overall, is more open to adapting to a changing environment. Not surprisingly, given its emphasis by the Rural Area Cooperative's management, "cooperative's training and technical support" for farmers is mentioned much more often by Rural Area Cooperative's than the Large Metro Area Cooperative's members (41.9 percent of the Large Metro Area Cooperative's versus 80.8 percent of the Rural Area Cooperative's members). The remaining indicator that increases the odds that we would predict that an individual is a member of the Rural Area Cooperative is satisfaction with the "milk price" paid by the cooperative (11.2 percent of the Large Metro Area Cooperative's members compared to 28.4 percent of the Rural Area Cooperative's members).

\section{Discussion}

From a research design point of view, the limitations of a study containing only two cases are clear and are being taken into account as we develop further research projects that seek to understand the sources of smallholder cooperative resilience. This includes building into the design a clearer set of cooperative histories and indicators to generate a truly comparable quasi-experimental design that would control for some variables and, thus, permit a more robust assessment of variables of central concern to policy makers and development professionals. Moreover, there is evidence that variations 
in what smallholders produce-e.g., coffee or milk or horticultural products—will have a substantial impact on the nature of their respective supply chains and, thus, in turn, the incentives for farmers to join a cooperative [30,31].

Nonetheless, the findings from the study reported in this paper do suggest specific analytical and research design areas on which to focus. Of particular interest is that our findings based on quantitative data are consistent with a number of comprehensive qualitative studies that have generated hypotheses [32] and have suggested a direction for building a comprehensive approach to development work with smallholder cooperatives. Four areas of convergence are described below.

\subsection{Greater Attention to the Role of Sub-National Market Rivalries on What Cooperatives Can Do to Incentivize Member Patronage}

Development theory and practice gives considerable attention to the changes in the national-level institutional environment and its likely impact on collective action projects. This is seen in the wealth of data provided by The World Bank on "ease of doing business", and other indicators of institutional supports for transparency in market transactions, as well as overall economic development indicators [33]. In addition, policy-makers and planners can access specific institutional supports for cooperatives.

Much less attention, however, has been given to how sub-national parameters generate constraints and opportunities that affect the likely success of strategies to build business plans that will maintain, or hopefully increase, member patronage in the cooperative. In the case of the Large Metro Area Cooperative, faced with an increasing competition from rivals and more options for different types of farming by their members, developed new selective incentives, including a dairy feed mill and a credit union. The Rural Area Cooperative, located in a different environment, was able to incentivize its members to support a more efficient business strategy, which meant reducing or eliminating support for some selective benefits, while placing a greater emphasis on an extension service to support the long-term development of members' dairy farm operations.

Our findings are consistent with the study of the Nunavik [14] in which an indigenous people were able to develop a sustainable economic adaptation to a rapidly-changing market for their products through the creation of an organization that was focused on collective entrepreneurship. Most important, this adjustment required a change in traditional social organization, but provided a solid institutional base to retain the core elements of their culture.

\subsection{Understanding the Role of Income in Member Engagement}

Our findings indicate that smallholder farmers can evaluate income from dairy in different ways. For non-members of cooperatives, it is clear that price is the most important criterion, which explains their preference to sell their milk to whomever offers the highest price. Obviously price is important to cooperative members as well, but it appears from the data that, compared to non-members, it is relatively less important (see Tables 2 and 3 ).

This does not mean, of course, that income is unimportant to cooperative members. Rather, it indicates, especially in the case of the Rural Area Cooperative, that members, as opposed to non-members, have a longer time perspective on their farm income. Being able to depend upon the cooperative to purchase their milk regardless of how much milk is available at different times of the year and, overall, the trust that the cooperative will support their long-term objective of becoming more successful dairy farmers (see Table 5). Most important, our findings reinforce those of other researchers who have shown that the desire of smallholders to preserve their farms and local communities is not, in any way, an obstacle to adopting new innovations [23,24].

Since the cooperative depends upon member patronage to remain sustainable, however, it is important that members' subjective judgments be taken into account. This includes identifying what members' perceive as specific benefits they receive from their cooperative. 


\subsection{The Inextricable Link between Business Strategies, Selective Incentives, Social Capital, and Evaluating Smallholder Cooperative Success}

A necessary condition for the long-term sustainability of smallholder cooperatives, like that of any business organization is to create a business plan that takes account of the market conditions in their environment. At the same time, however, cooperatives, by definition, require member patronage. Thus, they must somehow engage members in their business strategy [34]. The Rural Area Cooperative's more efficient business practices also included identifying ways to improve the performance of their members. Especially important here was the creation of an extension service to provide farmers with scientific information on ways to improve their production. This outreach activity, along with increased member satisfaction with improved management practices, such as better on-time payment and bonuses, have resulted in a substantial increase in the cooperative's social capital. This social capital, in turn, has produced high levels of member support for management's streamlining of milk collection routes and other newly-introduced efficiency measures.

\subsection{Developing Smallholder Cooperative Leadership Capacity}

One of the most striking findings in the two case studies is the manner in which a change in leadership resulted in an improvement in the financial situation in the two cooperatives and its relationship to member engagement. The situation in the Large Metro Area Cooperative was, in some ways, more challenging than in the case of the Rural Area Cooperative, but at least the new management was able to keep the cooperative afloat in spite of some very poor decisions in preceding years. In the Rural Area Cooperative, the change in leadership produced a wholesale positive change, not only in the cooperative's financial condition but also in the level of member engagement and overall satisfaction.

Especially in the case of the Rural Area Cooperative, it is clear that the turn around was the result of a new management team that contained both "hard" and "soft" skills. In the case of the former, this meant that the board had selected a manager with enough business training and experience to operate effectively in the newly-liberalized market environment. In the case of the latter, the new management recognized the essential role of social capital in generating member engagement in cooperatives and was able to develop specific programs to meet that need. Thus, in addition to improving fiscal management, one of the most important lessons about smallholder cooperatives learned from this project is that building social capital—trust and social network linkages-and employing leaders who include this goal as a core part of their business strategy, can produce substantial gains in cooperative firm performance and member satisfaction.

Equally important, in terms of our theoretical understanding of what produces sustainable smallholder cooperatives that can compete in the new environment in developing countries is how we define the role of the donor organization in leadership capacity building. In contrast to the top-down approach of many development projects, the Land O'Lakes International Development team entered the project without pre-conceived notions of what the local actors needed to succeed in making their cooperatives sustainable. Rather, the core assumption underlying the project was that in order to be successful, those who had a long-term stake in the cooperative, the members and the board representatives who they elected, and the management team selected by the board, would have to take ownership of whatever changes would be necessary to improve performance. The Land O'Lakes team provided the resources to obtain quantitative and qualitative data to measure the current situation faced by the cooperative-i.e., financial, member engagement, etc.-as well as consultants and workshop training experiences but, in the end, the cooperatives themselves were responsible for making decisions. This is consistent with other studies that "peer learning" or a "community of practice" [24] is more effective in promoting innovation among smallholders than is the imposition of technical assistance but leaves very few decisions to the farmer.

The aforementioned suggests, therefore, that perhaps donor organizations and their national and international funding sources should devote more resources to developing local leadership capacity, rather than simply providing equipment, infrastructure, and other material that oftentimes are under-utilized, or even disappear once the funding for the project has ended. Focusing more 
directly on the development of local capacity-building, which is a main goal of the new Localworks program within USAID, would seem to have more long-term benefits in terms of building sustainable locally-led development projects [35]. Rather than focus on training a few select leaders, who may or may not remain with the cooperative, this approach concentrates on understanding the complexities of the formal and informal institutional networks that have bearing on the long-term success of the organization. This includes identifying ways to connect with local networks of financial institutions, accountants and supply chain experts to support cooperative business growth. This, of course, requires resources to support projects that, in addition to objective performance indicators, also obtains over time quantitative and qualitative data on members' subjective satisfaction with various aspects of the cooperative.

Acknowledgments: The research for this article is made possible by the support of the United States Agency for International Development (AID-OAA-A-10-00016) under the Cooperative Development Program implemented by Land O'Lakes International Development (http://www.landolakes.org/). The contents of the article are the sole responsibility of the authors and do not necessarily reflect the views of USAID or the United States government.

Author Contributions: All of the authors contributed to the research design and analysis of this project.

Conflicts of Interest: The authors declare no conflict of interest.

\section{References}

1. Nyoro, J.K.; Ngugi, I.K. A qualitative analysis of success and failure factors of agricultural cooperatives in central Kenya. In Decentralization and the Social Economics of Development: Lessons from Kenya; Barrett, C.B., Mude, A.G., Omiti, J.M., Eds.; CABI: Wallingford, UK, 2007; pp. 12-32. Available online: http:/ /www.cabi. org/cabebooks/ebook/20073207858 (accessed on 30 June 2016).

2. O'Brien, D.J.; Cook, M.L. Smallholder dairy entities in East Africa: Challenges and opportunities. In'Cooperatives, Economic Democratization and Rural Development; Bijman, J., Schuurman, J., Muradian, R., Eds.; Edward Elgar: Cheltenham, UK, 2016; pp. 226-251.

3. O'Brien, D.J.; Banwart, L.; Cook, M.L. Measuring the benefits of smallholder farmer membership in producer controlled vertical value chains: Survey findings from a development project in East Africa. Poverty Public Policy 2013, 5, 399-416. [CrossRef]

4. Cook, M.L. The future of U.S. agricultural cooperatives: A neo-institutional approach. Am. J. Agric. Econ. 1995, 77, 1153-1159. [CrossRef]

5. Carboni, B.J.; Calderon, M.L.; Garrido, S.R.; Dayson, K.; Kickul, J.; Jill, K. Handbook of Microcredit in Europe: Social Inclusion through Microenterprise Development; Edward Elgar: Cheltenham, UK, 2010.

6. Olson, M., Jr. The Logic of Collective Action: Public Goods and the Theory of Groups; Harvard University Press: Cambridge, MA, USA, 1971.

7. Woolcock, M.; Narayan, D. Social capital: Implications for development theory, research and policy. World Bank Res. Obs. 2000, 15, 225-249. [CrossRef]

8. Midgley, J. Microenterprise, global poverty and social development. Soc. Work 2008, 51, 467-479. [CrossRef]

9. Lazzarini, S.; Chaddad, F.R.; Cook, M.L. Integrating supply chain and network analyses: A study of net chains. J. Chain Netw. Sci. 2001, 1, 7-22. [CrossRef]

10. Cook, M.L.; Plunkett, B. Collective Entrepreneurship: An emerging phenomenon in producer-owned organizations. Agric. Econ. Assoc. 2006, 38, 421-428.

11. Cook, M.L.; Burress, M.J. A Cooperative Life Cycle Framework; Hebrew University of Jerusalem: Jerusalem, Israel, 2009.

12. LeCren, N.; Lyons, J.; Dana, L.P. The role of collective action in the New Zealand dairy industry: An international comparison. Int. J. Entrep. Small Bus. 2009, 8, 154-169.

13. Dana, L.P.; Dana, T.E. Collective Entrepreneurship in a Mennonite Community in Paraguay. Lat. Am. Bus. Rev. 2008, 8, 82-96. [CrossRef]

14. Dana, L.P. Nunavik Arctic Quebec: Where cooperatives supplement entrepreneurship. Glob. Bus. Econ. Rev. 2010, 12, 42-71. [CrossRef]

15. Williamson, O.E. The Economic Institutions of Capitalism; The Free Press: New York, NY, USA, 1985.

16. Fischer, E.; Qaim, M. Linking smallholders to markets: Determinants and impacts of farmer collective action in Kenya. World Dev. 2011, 40, 1255-1268. [CrossRef] 
17. Markelova, H.; Mwangi, E. Collective action for smallholder market access: Evidence and implications for Africa. Rev. Policy Res. 2010, 27, 621-640. [CrossRef]

18. Valentinov, V. Why are cooperatives important in agriculture? An organizational economics perspective. J. Inst. Econ. 2007, 3, 55-69. [CrossRef]

19. Roy, D.; Thorat, A. Success in high value export markets for the small farmers: The case of Mahagrapes in India. World Dev. 2008, 36, 1874-1890. [CrossRef]

20. Poulton, C.; Dorward, A.; Kydd, J. The future of small farms: New directions for services, institutions, and intermediation. World Dev. 2010, 38, 1413-1428. [CrossRef]

21. Sgroi, F.; di Tapani, A.M.; Tudisca, S. Strategy to increase the farm competitiveness. Am. J. Agric. Biol. Sci. 2014, 9, 394-400. [CrossRef]

22. Diederen, P.; Van Meiji, H.; Wolters, A. Modernisation in agriculture: What makes a farmer adopt an innovation? Int. J. Agric. Res. Gov. Ecol. 2003, 2, 328-342. [CrossRef]

23. Beckford, C.L. Decision-making and innovation among small-scale yam farmers in central Jamaica: A dynamic, pragmatic and adaptive process. Geogr. J. 2002, 168, 248-259. [CrossRef]

24. Dolinska, A.; d'Aquino, P. Farmers as agents in innovation systems: Empowering farmers for innovation through communities of practice. Agric. Syst. 2014, 142, 122-130. [CrossRef]

25. Schneiberg, M.; King, M.; Smith, T. Social movements and organizational form: Cooperative alternatives to corporations in the American insurance, dairy and grain industries. Am. Sociol. Rev. 2008, 73, 635-667. [CrossRef]

26. O’Brien, D.J.; Phillips, J.L.; Patsiorkovsky, V.V. Linking Indigenous Social Capital to the Global Economy. Reg. Stud. 2005, 31, 1041-1051. [CrossRef]

27. Cook, M.L.; Burress, M.J. The impact of CEO tenure on cooperative governance. Manag. Decis. Econ. 2013, 34, 218-229. [CrossRef]

28. Langworthy, M.; Banwart, L.O. Land O'Lakes Cooperative Development Project (CDP): Quantitative Performance Evaluation (QPE); Tango International: Tuscon, AZ, USA, 2015.

29. The Net Promoter Score. Net Promoter Network. 2016. Available online: https://www.netpromoter.com/ know / (accessed on 15 March 2016).

30. Barrett, C.B. Smallholder market participation: Concepts and evidence from eastern and southern Africa. Food Policy 2008, 33, 299-317. [CrossRef]

31. Reardon, T.; Barrett, C.B.; Berdegue, J.A.; Swinnen, J.F.M. Agrifood industry transformation and small farmers in developing countries. World Dev. 2009, 37, 1717-1727. [CrossRef]

32. Dana, L.P.; Dumez, H. Qualitative research revisited: Epistemology of a comprehensive approach. Int. J. Entrep. Small Bus. 2015, 26, 154-170. [CrossRef]

33. The World Bank. Ease of Doing Business Index; The World Bank: Washington, DC, USA, 2015; Available online: http:/ / data.worldbank.org/indicator/IC.BUS.EASE.XQ (accessed on 12 March 2016).

34. Zakic, S.; Laketa, M.; Laketa, L. Agricultural cooperatives: Researching members' perception of important issues of co-operatives on the example of Serbia. Anim. Plant Sci. 2013, 23, 290-297.

35. Localworks Program. United States Agency for International Development: Washington, DC, USA, 2016. Available online: https://www.usaid.gov/partnership-opportunities/ngo/localworks (accessed on 6 April 2016).

(c) 2016 by the authors; licensee MDPI, Basel, Switzerland. This article is an open access article distributed under the terms and conditions of the Creative Commons Attribution (CC-BY) license (http://creativecommons.org/licenses/by/4.0/). 